\title{
THE INTEGRITY OF DNA EXTRACTED FROM ORYCTOLAGUS CUNICULUS CARCASSES TREATED WITH DIFFERENT CORROSIVE CHEMICAL SUBSTANCES
}

\author{
Onyekachi O. Iroanya ${ }^{\text {a }}$, Jeffrey O. Ogbeide a , Tochukwu F. Egwuatu ${ }^{\text {a }}$ \\ ${ }^{a}$ Department of Cell Biology and Genetics, University of Lagos, Akoka Yaba, Lagos Nigeria (oiroanya@unilag.edu.ng; \\ jeffzyme@gmail.com; tochukwufrankegwuatu@gmail.com)
}

\begin{abstract}
:
There is a gap in the literature concerning the use of corrosive chemicals to erode human body. The aim of this study is to determine the integrity of DNA samples extracted from rabbits' carcasses immersed in different chemical. Twenty-one healthy rabbits were grouped into seven. Animals in group 1 were enclosed in transparent containers while groups 2 to 7 were submerged in $1 \%$ hydrochloric acid $(\mathrm{HCl})$, sodium hypochlorite $(\mathrm{NaClO})$, calcium hypochlorite $\left(\mathrm{CaOCl}_{2}\right), 7.3 \%$ sodium hydroxide $(\mathrm{NaOH})$, water and $35 \% \mathrm{HCl}$ respectively. Tissue sample were collected on day(s) 1, 3, 7 and 12 for DNA extraction and analysis. The most destructive agent in this study was $35 \% \mathrm{HCl}$ where the bones and almost all tissues degraded within $24 \mathrm{hrs}$, followed by Sodium hydroxide while, there was no marked degradation in $\mathrm{NaClO}, \mathrm{CaOCl}_{2}$, water and dilute $\mathrm{HCl}$ groups. Distinct, observable effects of each chemical on the extracted DNA samples revealed decreased DNA integrity and degradation at various time frames. Further studies need to be carried out to ascertain the concentration of these chemicals especially $\mathrm{NaOH}$ that will completely destroy the body of the rabbits within a short period of time. Chromosomal aberration analysis should also be included in future research.
\end{abstract}

KEYWORDS: DNA integrity, DNA degradation, Bone, Tissue, corrosive chemicals, hydrochloric acid, Sodium hydroxide

\section{INTRODUCTION}

The act of destroying human corpses by immersing them in corrosive chemicals such as acids or some other caustic substances in order to avoid any personal identification is becoming relevant in forensic sciences. The nature of crime is changing daily and the forensic scientist is always facing new challenges regarding the process of identification. The reason for such crime is to destroy any physical evidence of cause of death, time interval of death to body identification, and victim identification. In such cases, whole body is singed and corroded and as such very few identification marks are observed. Whenever acid and other corrosive substances come in contact with the skin, acid melts skin tissue and soft tissues exposing the hard tissues (Poetsch et al., 1992). Caustic substances cause tissue destruction through liquefaction and the intensity of destruction depends on the type, concentration, time of contact and amount of the substance that one is in contact with (Mamede and Filho, 2001).

Extraction of DNA from soft tissues of dead bodies immersed in acid and other corrosive chemicals, has proven to be hard and almost impossible (Mazza et al., 2005). Acid immersion of victim's body is one of the methods employed to subvert identification of the victim, and hence of the perpetrator. Analysis of DNA is a crucial method employed in forensic investigation of biological fluids with a higher degree of certainty (Sowmya et al., 2013). Forensic DNA analysis routinely deals with materials recovered from crime scenes, paternity testing and the identification of human remains (Jobling and Gill, 2004). Very few studies exist on the isolation of DNA from tissues of dead bodies after they have been immersed in acids and other corrosive chemicals. The aim of this study was to determine the integrity of DNA samples extracted from rabbits' carcasses immersed in solutions of $35 \% \mathrm{HCl}$, dilute $\mathrm{HCl}, \mathrm{NaClO}, \mathrm{CaOCl}_{2}, \mathrm{NaOH}$ and tap water for $1,3,7$ and 12 days respectively.

\section{MATERIALS AND METHODS}

\subsection{Materials used}

The following materials were used for this study; Quick-DNA Miniprep Plus, Zymo Research Kit, Agarose powder (Cleaver Scientific Ltd), Sodium hypochlorite ( $\mathrm{NaClO}$ ) (Hypo bleach), Calcium hypochlorite $\left(\mathrm{CaOCl}_{2}\right)$, hydrochloric acid $(\mathrm{HCl})$ and Sodium hydroxide $(\mathrm{NaOH})$ (Merck $\mathrm{KGaA}$, Darmstadt, Germany). All other chemicals were of analytical grade.

\subsection{Experimental animals}

Twenty-one (21) rabbits were used for this study and they were obtained from a farm. The animals were housed in rabbits' cages at normal room temperature with dark and light cycle (12/12 hr). They were fed with vegetables and tap water ad libitum. The animals were kept for two weeks in order to ensure proper acclimatization. The average weight of all rabbits was $4.8 \mathrm{~kg}$. Experiment was carried out in the animal house of the Institution.

* Corresponding author

This is an open access under a CC BY-NC-SA 4.0 license (https://creativecommons.org/licenses/by-nc-sa/4.0/) 


\subsection{Ethical issues}

This research was performed according to the Organization of Economic Co-operation and Development (OECD) guidelines for testing Chemical, TG425 (OECD, 2001). This study was conducted according to the rules and regulations of the University Ethical Committee on the use of experimental animals.

\subsection{Grouping of the animals}

All the rabbits were separated into seven groups, with three (3) animals in each group. Animals in group 1 were placed in three different transparent containers and were labelled respectively. Three litres of each chemical used in this study were measured and poured into each container for the different groups, thereafter, each rabbit was sacrificed and immersed in each airtight transparent container. In groups 2- 7, all the animals were immersed in different transparent containers for each group using $1 \% \mathrm{HCl}$ (group 2), sodium hypochlorite $(3.5 \mathrm{w} / \mathrm{v})$ with brand name Hypo (group 3), $7.5 \%$ calcium hypochlorite $\mathrm{CaOCl}_{2}$ (group 4), $7.3 \%$ sodium hydroxide $(\mathrm{NaOH})$ solution (group 5), tap water (group 6) and $35 \% \mathrm{HCl}$ (group 7) respectively.

\subsection{Sample collection}

Sample collection was carried out on days 1, 3, 7 and 12. On day one, soft tissue samples were collected from the hind limbs (muscle) of the rabbits for DNA extraction from all the rabbits immediately after they were sacrificed by cervical dislocation before commencing the experiment. The animals in the control group were not immersed in any solution. On days three, seven and twelve, tissue samples were collected from all groups for DNA extraction and analysis. Additionally, both the control and experimental groups were observed on day 38 but samples were not taken for DNA extraction

\subsection{DNA extraction}

Deoxyribonucleic acid samples were extracted from soft tissue samples collected from the rabbits' hind limbs (muscle) using Quick-DNA Miniprep plus Kit purchased from Zymo Research through Inqaba, Ibadan, Oyo State, Nigeria. Approximately 25 $\mathrm{mg}$ of each tissue sample was collected into a micro-centrifuge tube and $95 \mu \mathrm{l}$ of sterile distilled water, $95 \mu \mathrm{l}$ of solid tissue buffer and $10 \mu \mathrm{l}$ of Proteinase K were added. The microcentrifuge tube with the tissue sample and the solution was thoroughly mixed and incubated at $55{ }^{\circ} \mathrm{C}$ for 3 hours (until tissue solubilized). The insoluble debris was removed by centrifuging at $12000 \mathrm{x} g$ for 1 minute and transferred into a clean microcentrifuge tube. Double volume (supernatant) Genomic Buffer was added to the supernatant and mixed thoroughly. The mixture was transferred to a Zymo-Spin ${ }^{\mathrm{TM}}$ IIC-XL Column in a Collection Tube, centrifuged at $12000 \mathrm{x}$ g for 1 minute and the collection tube was discarded with the flow through. Four-hundred microlitres of DNA pre-wash buffer was added to the column in a new collection tube and centrifuged for 1 minutes at $12000 \mathrm{x}$ g. The collection tube was emptied. Seven-hundred microlitre g-DNA wash buffer was added and centrifuged for 1 minute at $12000 \mathrm{x}$ g. The collection was emptied and $200 \mu \mathrm{lg}$-DNA wash buffer was added and centrifuged for 1 minute at $12000 \mathrm{x}$ g. The collection tube was discarded with the flow through. The sample was then transferred to a clean microcentrifuge tube and approximately 50 $\mu 1$ DNA elution buffer was added to elute the DNA. It was then incubated for 5 minutes and then centrifuged for 1 minute at $12000 \mathrm{x}$ g and stored at $-20{ }^{\circ} \mathrm{C}$.

\subsection{Spectrophotometry}

Spectrophotometry of the extracted DNA samples was carried out by exposing the samples to UV wavelengths $260 \mu \mathrm{m}$ and $280 \mu \mathrm{m}$ using a spectrophotometer (Eppendorf BioPhotometer plus). The optical density of the samples was observed and recorded.

\subsection{Gel electrophoresis}

One gram of the agarose powder was dissolved in $100 \mathrm{ml}$ of 0.5 $\mathrm{x}$ TBE solution by boiling in a hot plate. It was then allowed to cool to approximately $60^{\circ} \mathrm{C}$ and 2 drops of ethidium bromide was then added. The mixture was mixed gently and a gel thickness of about 4-5 $\mathrm{mm}$ was obtained by pouring into a taped electrophoresis tray with the comb and allowed to solidify for 20 minutes. The rubber dam and the comb were removed carefully to avoid damaging the gel. The tray was placed in an electrophoresis tank (Bio -Rad Power-pack) and 0.5 x TBE gel buffer was poured the first well of all gels before loading the samples. Five microlitres $(5 \mu \mathrm{l})$ of loading dye was mixed with 5 $\mu \mathrm{l}$ of the sample. The mixture was loaded into a comb well. Electrophoresis was then initiated at $60-100 \mathrm{~V}$ until the loading dye has migrated three quarter of the gel. Bands of the DNA on the agarose gel containing the extracted samples were observed through transillumination with the use of ultra-violet ray transilluminator (Fisher Biotech).

\subsection{Statistical analysis}

All the data obtained from this study were analysed statistically using Microsoft Excel version 2010. The data are presented as bar charts.

\section{RESULTS}

Spectrophotometry check was used to measure the absorbance of light by measuring the intensity of light as a beam of light passed through the sample solutions. This was carried out to determine the purity and molecular concentration of the extracted DNA samples. On Day One, Group one was observed to have a mean \pm SE purity of $1.74 \pm 0.02$ with a mean \pm SE concentration of 436 \pm 54.08 . However, the highest mean $\pm \mathrm{SE}$ concentration that was observed on day one was that of Group 4 which was $1301.33 \pm$ 74.18. On Day Three, Group two showed a drop in DNA purity when compared to Day One from $1.46 \pm 0.09$ to1.41 \pm 0.09 . In comparison with the control, it was observed that Group two had a mean \pm SE purity a little bit higher than the control which was $1.41 \pm 0.09$ as against the control which was $1.33 \pm 0.06$. Also, the mean \pm SE concentration of DNA was lower than that of control which $201.33 \pm 68$ as against $252.67 \pm 82.72$. On Day Seven, Group three's purity was lower and better than that of Day $3(1.66 \pm 0.01$ as against $2.71 \pm 0.05)$. While the mean $\pm \mathrm{SE}$ concentration was observed to be higher, $674.67 \pm 125.29$ as against $362 \pm 112.57$. Furthermore, the purity and concentration mean $\pm \mathrm{SE}$ values of this were observed to be higher than the control $1.66 \pm 0.01$ as against $1.08 \pm 0.06$ and $674.67 \pm 125.29$ as against $134.33 \pm 32.62$. On Day twelve, Group four had a decline in the mean \pm SE purity values from day 7 to day 12 , (from $1.42 \pm$ 0.02 to $1.34 \pm 0.08$ ). The mean $\pm \mathrm{SE}$ concentration values also declined from day 7 to $12,(159.67 \pm 21.06$ to $114 \pm 0.02)$. The mean \pm SE purity values of this group was higher than the control $1.19 \pm 0.03$ but the control had a higher mean \pm SE concentration values of $895.33 \pm 510.29$ as shown in table 1 . While group 7 had both flesh and bones eroded. Though, charred black tissues which readily dissolved on touching were observed on day 3 and day 7 . No remnant of bone was seen, because all the bones were completely dissolved. 
There was a gradual decrease in mean purity for all groups from day 1 to day 12 except for group 3 which showed extremely high purity value of 2.7 on day 3 and this indicates possible presence of proteins in the DNA samples. There was a non-coherent increase and decrease in mean DNA concentration from day 1 to day 12.

The Plates below show various decomposition rates of the rabbits used in this study in various chemical substances.

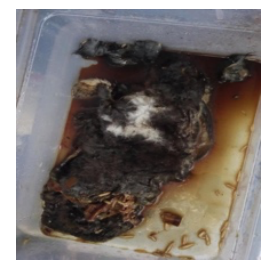

Plate 1: Carcass of a rabbit (Group 1) which was not immersed in any chemical solution on day 3

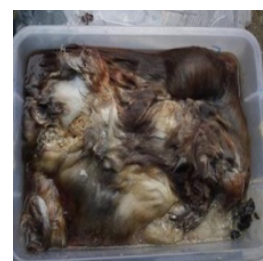

Plate 3: Carcass of a rabbit (Group 6) immersed in $\mathrm{H}_{2} \mathrm{O}$ on day 3

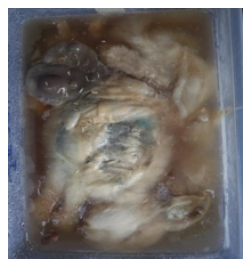

Plate 5: Carcass of a rabbit (Group 2) immersed in dilute $\mathrm{HCl}$ on day 7

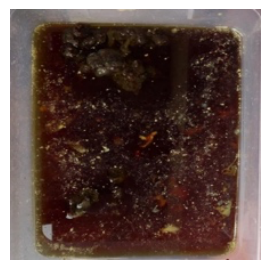

Plate 2: Carcass of a rabbit (Group 5) immersed in $\mathrm{NaOH}$ solution on day 3

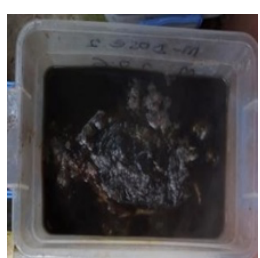

Plate 4: Carcass of a rabbit (Group 7) immersed in 35\% $\mathrm{HCl}$ solution on day 3

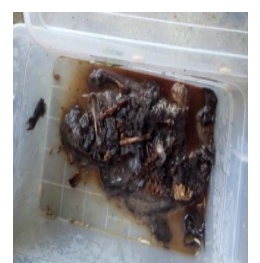

Plate 6: Carcass of a rabbit (Group 1) which was not immersed in any chemical solution on day 12

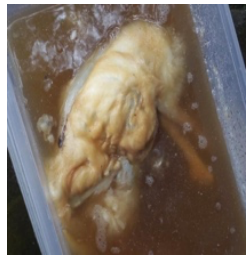

Plate 7: Carcass of a rabbit (Group 3) immersed in $\mathrm{NaClO}$ solution on day 12

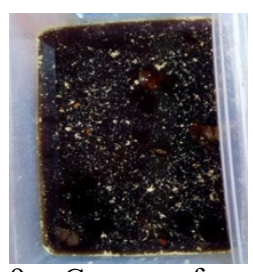

Plate 9: Carcass of a rabbit (Group 5) immersed in $\mathrm{NaOH}$ solution on day 12

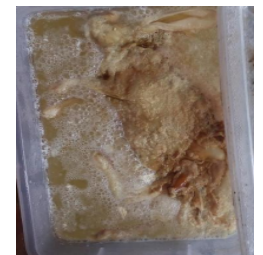

Plate 8: Carcass of a rabbit (Group 4) immersed in $\mathrm{CaOCl}_{2}$ solution on day 12

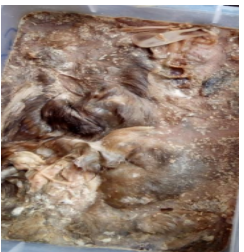

Plate 10: Carcass of a rabbit (Group 6) immersed in $\mathrm{H}_{2} \mathrm{O}$ on day 12
There was also a gradual decrease in DNA quality for all groups from day 1 to day 12 . Plates 11 and 12 show bands of DNA extracted from all samples on day 1. Lane 1 indicates bands of the DNA ladder while lanes 2 to 20 indicate DNA extracted from experimental samples. Bands were detected on lane 3, 4, 5, 7-20. On day 3 , in plate 13, the DNA samples appeared smeared indicating that the DNA samples are degraded, plates 14 1nd 15 showed few distinct bands for lanes $27,30,32,33,35,37$. On day 7 , in plate 16 , DNA samples 45, 51,52 and 54 appeared smeared indicating that the DNA samples were degraded, while other samples did not appear on the transilluminator. Plate 17, on day 12 revealed faint smeared bands on lanes 66 and 72. Other DNA samples showed no band.

The Plates below show various gel images obtained from gel electrophoresis of all DNA samples extracted from rabbits' soft tissues.

\begin{tabular}{|c|c|c|c|c|c|c|c|c|c|c|c|c|c|}
\hline \multirow[t]{2}{*}{ Groups } & \multirow{2}{*}{\begin{tabular}{|l} 
Purity \\
and \\
Conc \\
(ng/ul)
\end{tabular}} & \multicolumn{3}{|c|}{ Day 1} & \multicolumn{3}{|c|}{ Day 3} & \multicolumn{3}{|c|}{ Day 7} & \multicolumn{3}{|c|}{ Day 12} \\
\hline & & Min & Max & Mean \pm SE & Min & Max & Mean \pm SE & Min & Max & Mean \pm SE & Min & Max & Mean \pm SE \\
\hline \multirow{2}{*}{$\begin{array}{l}1 \\
\text { Control }\end{array}$} & Purity & 1.69 & 1.77 & $1.74 \pm 0.02$ & 1.25 & 1.44 & $1.33 \pm 0.06$ & 0.98 & 1.18 & $1.08 \pm 0.06$ & 1.09 & 1.25 & $1.19 \pm 0.03$ \\
\hline & Conc & 335 & 520 & $436 \pm 54.08$ & 165 & 418 & $252.67 \pm 82.7$ & 74 & 186 & $134.33 \pm 32.6$ & 76 & 1832 & $895.33 \pm 510.3$ \\
\hline \multirow{2}{*}{$\begin{array}{l}2 \\
\mathrm{HCl}\end{array}$} & Purity & 1.39 & 1.53 & $1.46 \pm 0.04$ & 1.22 & 1.53 & $1.41 \pm 0.09$ & 1.26 & 1.49 & $1.38 \pm 0.07$ & 1.19 & 1.43 & $1.28 \pm 0.08$ \\
\hline & Conc & 25 & 354 & $140.33 \pm 107$ & 128 & 339 & $201.33 \pm 68$ & 165 & 214 & $189.7 \pm 14.15$ & 113 & 1743 & $688.7 \pm 527.91$ \\
\hline \multirow[t]{2}{*}{$3 \mathrm{NaClO}$} & Purity & 1.37 & 1.45 & $1.41 \pm 0.02$ & 2.62 & 2.78 & $2.71 \pm 0.05$ & 1.65 & 1.67 & $1.66 \pm 0.01$ & 1.19 & 1.25 & $1.22 \pm 0.02$ \\
\hline & Conc & 24 & 244 & $107 \pm 69.02$ & 153 & 539 & $362 \pm 112.57$ & 458 & 892 & $674.7 \pm 125.3$ & 792 & 2002 & $1221 \pm 341.13$ \\
\hline \multirow{2}{*}{\begin{tabular}{|c|}
4 \\
$\mathrm{CaOCl}_{2}$ \\
\end{tabular}} & Purity & 1.48 & 1.56 & $1.51 \pm 0.24$ & 1.40 & 1.46 & $1.42 \pm 0.02$ & 1.28 & 1.52 & $1.40 \pm 0.07$ & 1.25 & 1.50 & $1.34 \pm 0.08$ \\
\hline & Conc & 74 & 2214 & $1301.3 \pm 678$ & 79 & 716 & $311 \pm 203.22$ & 129 & 200 & $159.67 \pm 21.1$ & 80 & 150 & 114 \\
\hline \multirow{2}{*}{$\begin{array}{l}5 \\
\mathrm{NaOH}\end{array}$} & Purity & 1.48 & 2.99 & $2.07 \pm 0.05$ & 1.05 & 1.13 & $1.08 \pm 0.02$ & 1.04 & 1.13 & $1.08 \pm 0.02$ & 1.03 & 1.15 & $1.09 \pm 0.03$ \\
\hline & Conc & 47 & 270. & $121.7 \pm 74.2$ & 31 & 84 & $62 \pm 15.95$ & 102 & 203 & $143.3 \pm 30.56$ & 30 & 316 & $145 \pm 87.18$ \\
\hline \multirow{2}{*}{$\begin{array}{l}6 \\
\mathrm{H}_{2} \mathrm{O} \\
\end{array}$} & Purity & 1.61 & 1.71 & $1.65 \pm 0.03$ & 1.37 & 1.71 & $1.65 \pm 0.02$ & 1.12 & 1.93 & $1.42 \pm 0.02$ & 1.16 & 1.32 & $1.25 \pm 0.05$ \\
\hline & Conc & 41 & 135 & $29.95 \pm 0.02$ & 120 & 460 & $332.3 \pm 106.9$ & 22 & 2423 & $858.3 \pm 783$ & 63 & 2041 & $732.7 \pm 654.23$ \\
\hline \multirow{2}{*}{$\begin{array}{l}7 \\
\text { Conc } \\
\mathrm{HCl}\end{array}$} & Purity & 1.49 & 1.67 & $1.55 \pm 0.02$ & -- & -- & -- & -- & -- & -- & -- & -- & -- \\
\hline & Conc & 65 & 152 & $114.6 \pm 94.8$ & -- & -- & - & -- & -- & -- & -- & -- & -- \\
\hline
\end{tabular}




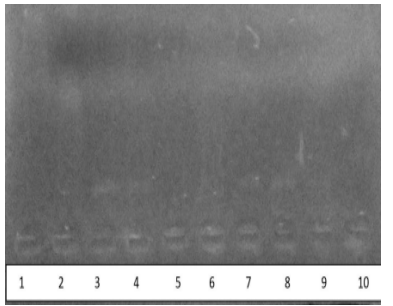

Plate 11 shows bands of DNA extracted from all samples on day 1

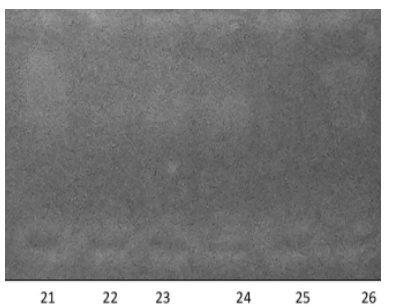

Plate 13 shows bands of DNA extracted from all samples on day 3

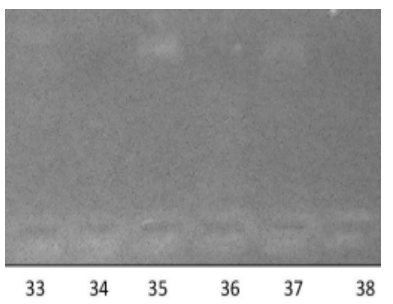

Plate 15 shows bands of DNA extracted from all samples on day 3

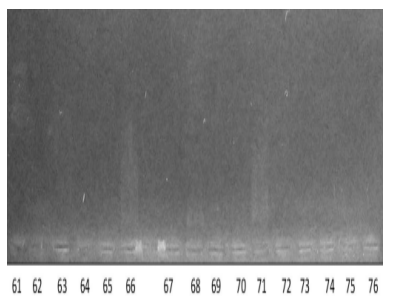

Plate 17 shows bands of DNA extracted from all samples on day 12

\section{DISCUSSION}

Attacks using acids and other corrosive chemical agents are carried out by criminals in order to avoid any personal identification of their victims in crimes which are of great interest to forensic scientists (Raj et al., 2013). The findings of this study revealed that several types of easy-to-access corrosive substances are capable of destroying tissues and consequently could be used to eliminate pieces of evidence and features which are useful for identification in forensic investigations.

The set of animals in the control group (Group 1) decomposed gradually because they were not subjected to any chemical treatment. On day 3 , the carcasses of the rabbits were still intact as no visible degradation was observed while on day 7, their internal organs were fully decomposed as observed. On day 12 ,

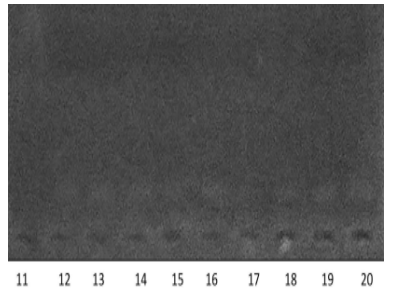

Plate 12 shows bands of DNA extracted from all samples on day 1

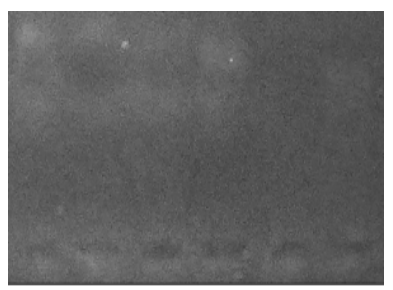
Plate 14 shows bands of DNA extracted from all samples
on day 3 on day 3

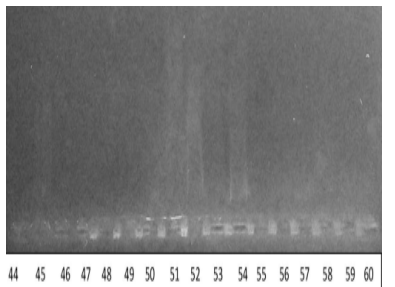

Plate 16 shows bands of DNA extracted from all samples on day 7

their skeletal structures were visible as all body tissues were fully decomposed. Subsequently, on day 38, Group 1 animals were completely decomposed while body parts such as fur, bones and few soft tissues were seen in Group 2 container. This agrees with the findings of Odo et al, (2017) who reported that the flesh decomposition stage of rabbits lasted for 0-12 days while skeletonization lasted for 7-46 days. On day 3 of experiment, all the tissues of Group 2 animals were observed to be intact. On day 7 , the internal organs were in shape but gradual decomposition was observed. On day 12 it was observed that further degradation of the rabbits' carcasses took place. This may be due the concentration of $\mathrm{HCl}$ used in this research which was too low to erode their flesh. The control (Group 1) decomposed faster than Group 2 and this was due to delayed or reduced microbial activity caused by dilute $\mathrm{HCl}$ just like in the case of the human stomach (Tennant et al., 2008). 
For Group 3 and Group 4 on day 3 of the experiment, the entire carcasses of the rabbits were observed to be intact. On day 7 , little decomposition was observed as tissues became soft. On day 12 , it was observed that no meaningful decomposition occurred. The choking smell of $\mathrm{NaClO}$ was observed in all days of experiment. The $\mathrm{NaClO}$ and $\mathrm{CaOCl}_{2}$ being antiseptic agents probably prevented microbial degradation of the animals (Seymour, 1991). This agrees with the findings of Hartnett et al, (2011) who discovered that household bleach (sodium hypochlorite) had no structural effects on their samples. Also, the gel electrophoresis of the DNA samples of both groups revealed that on day 3 DNA samples had low integrity. Also, on day 38, all the rabbit carcasses Groups 3 and 4 were partly degraded.

On day 3 of the experiment, the rabbit carcasses in Group 5 were completely eroded but, the lower jaw bone and small pieces of tissue were seen. On the 7 th day, only small bone fragments were seen. These bone fragments were very soft that they broke into tiny pieces on mere contact. On day 12 , only the faecal materials from the bowels of the rabbits were clearly seen. Bone fragments were still present in the solution on the 12th day. Very pale yellowish substance like fat was seen floating on top of the caustic soda solution. This disagrees with report of Hartnett et al., (2011) who documented that lye (sodium hydroxide) had no significant structural effects on their samples. Additionally, Cope and Dupras (2009), found that sodium hydroxide was the least effective agent they tested in degrading teeth. The severity of tissue damages caused by caustic substances on tissue depends on the type, quantity and concentration of the caustic substance. Caustic substances have a great potential for tissue destruction (Mamede and Filho, 2001). For Group 6, on day 3 of experiment, bloating was observed, gradual decomposition was also reported and foul smell was perceived from the containers of the specimens. On days 7 and 12, the carcasses were more degraded, as the internal organs had all decomposed. However, their skeletal structures, skin and furs were not degraded. The skins of the carcasses were seen spanning the entire containers. Foul decomposition odour oozed out the containers. Also, on day 38, all the rabbit carcasses Group 6 were completely degraded except their bones which were intact. However, Hartnett et al, (2011) reported that tap water had no effect on any of the human tissue tested during the timeframe of their study.

For Group 7, both bones and soft tissues of the rabbits completely eroded before day 3 . This agrees with the findings of Ramesh et al, (2015) who reported a complete dissolution of human teeth samples when treated with concentrated $\mathrm{HCl}$. Though, charred black tissues which readily dissolved on touching them were observed on day 3 and day 7 . Bloating was not observed in all the animals in this group. This implies that the solution was too acidic for proliferation of microorganisms that drive decomposition process. No remnant of bone was seen, all bones completely dissolved. This is in agreement with the study carried out by Hartnett et al., (2011) and Jadhav et al., (2009) who reported that hydrochloric acid was the most destructive agent of tissues in their study, consuming most tissues within $15 \mathrm{~h}$ and $24 \mathrm{~h}$ respectively. However, Robino, et al., 2015 stated that results from their research indicates that DNA profiling of acid-treated body parts (in particular, cortical bone) is still feasible at advanced stages of corrosion, even when the morphological methods used in forensic anthropology and odontology can no longer be applied for identification purposes.

\section{CONCLUSION}

This study revealed that sodium hypochlorite $(\mathrm{NaClO})$, dilute hydrochloric acid $\mathrm{HCl}$, calcium hypochlorite $\mathrm{CaOCl}_{2}$ and water do not have the ability to destroy the carcasses of the rabbits as their carcasses were still seen on 12 day of the experiment. However, $1.87 \mathrm{M}$ sodium hydroxide $(\mathrm{NaOH})$ destroyed the body of animals leaving small bone fragments behind within 3 days. The $35 \% \mathrm{HCl}$ was observed to be the most potent amongst all the chemical agents used in this study, as it eroded both flesh and bones of the rabbits' carcasses. Calcium hypochlorite will take longer period of time to erode the rabbits' carcasses but probably might not have any effect on the bones. Additionally, immersing carcasses into these chemicals resulted to low DNA integrity and increased DNA degradation. Further studies need to be carried out to ascertain what concentration of $\mathrm{NaOH}$ would destroy the body of the rabbits within a shorter period of time. The major limitation in the experimental setup was the choice of an animal model to simulate a situation whereby human bodies are dissolved in corrosive chemicals. The findings of the study indicate that DNA of appreciably good quality and yield can be extracted from rabbits' carcasses even at advanced stages of corrosion, especially when the morphological methods used in forensic anthropology can no longer be used for identification purposes.

\section{REFERENCES}

Cope, D. J. \& Dupras, T. L. (2009). The effects of household corrosive chemicals on human dentition. Journal of Forensic Science. 54(6), 1238-1246. DOI: 10.1111/j.1556-4029.2009.01147.x.

Hartnett, K. M, Fulginiti, L. C, \& Di Modica, F. (2011). The effects of corrosive substances on human bone, teeth, hair, nails, and soft tissue. Journal of Forensic Science. 56(4), 954-959. DOI: 10.1111/j.1556-4029.2011.01752.x.

Jadhav K., Gupta, N., Mujib, B. R. \& Amberkar, V. S. (2009). Effects of acids on the teeth and its relevance in postmortem identification. Journal of Forensic Science. 1, 93-98. DOI: $10.4103 / 0974-2948.60381$

Jobling, M.A., \& Gill P. (2004). Encoded evidence: DNA in forensic analysis. Nature Review Genetics. 5(10), 739-51. DOI: $10.1038 / \mathrm{nrg} 1455$

Mamede, R. C. M. \& Filho, F. V. M. (2001). Ingestion of caustic substances and its complications. Sao Paulo Medical Journal.

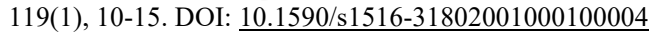

Mazza, A., Meralati, G., Savio, C., Fassina, G., Menaghini, P. \& Danesino, P. (2005). Observations on Dental Structures when Placed in Contact with Acids: Experimental Studies to Aid Identification Processes. Journal of Forensic Science. 50,406410. PMID: 15813552

Odo, P. E., Chidi, O. H. \& Iloba, B. N. (2017). Insects fauna associated with decomposing rabbit carrion in Falcorp mangrove park, Ijala, Warri, Delta State, Nigeria. Proceedings of the $4^{\text {th }}$ Delta State University Faculty of Science International Conference

Poetsch, L., Meyer, U., Rothschild, S., Schneider, P. M. \& Rittner, C. (1992). Application of DNA techniques for identification using human dental pulp as a source of DNA. International Journal of Legal Medicine. 105(3),139-143. DOI: https://doi.org/10.1007/BF01625165

Raj., M., Boaz, K \& Srikant, N. (2013). Are teeth evidence in acid environment? Journal of Forensic Dental Sciences. 5(1), 710. DOI: $10.4103 / 0975-1475.114536$

Ramesh, G., Seth, R. K., Mishra, G., Raj, A., Sing, S, \& Chaubey, S. (2015). Effect of concentrated acids on soft and hard tissue: a macroscopic analysis. University Journal of Dental Sciences. 1, 320-324.

Robino, C., Pazzi, M., Di Vella, G., Martinelli, D., Mazzola, L., Ricci, U., Testi, R., \& Vincenti, M. 2015. Evaluation of DNA typing as a positive identification method for soft and hard 
tissues immersed in strong acids. Legal Medicine. 17(6), 569-575. DOI.org/10.1016/j.legalmed.2015.07.004.

Seymour, S. B. (1991) "Disinfection, Sterilization and Preservation", 4th edition. Philadelphia Lea and Febiger,

Sowmya, K., Sudheendra, U. S., Khan, S., Nagpal, N. \& Prathamesh, S. J. (2013). Assessment of morphological changes and DNA quantification: An in vitro study on acid-immersed teeth.
Journal of Forensic Dental Sciences. 5(1), 42-46. DOI: 10.4103/0975-1475.114560

Tennant, S. M., Hartland, E. L., Phumoonna, T., Lyras, D., Rood, J. I., Robins-Browne, R. M. \& van-Driel, I. R. (2008). Influence of Gastric Acid on Susceptibility to Infection with Ingested Bacterial Pathogens. Infection and Immunity. 76(2), 639-645. DOI: 10.1128/IAI.01138-07 